\title{
20: 472482-411340
}

National Cancer Institute

\section{Source}

National Cancer Institute. 20:472482-411340. NCI Thesaurus. Code C42011.

Physical location of CSNK2A1_Gene 